\title{
Effects of Copper Nicotinate Complex on Renal Metallothionein and Metal-Responsive Transcription Factor 1 Genes Expression During 4-Dimethylaminoazobenzene Exposure in Rats
}

\author{
Neveen A Hussein $^{1 ¥}$, Mona AH Yehia ${ }^{2}$ \\ ${ }^{1}$ Applied Medical Chemistry Department, Medical Research Institute, Alexandria University, Alexandria, Egypt. \\ ${ }^{2}$ Histochemistry and Cell Biology Department, Medical Research Institute, Alexandria University, Alexandria, Egypt.
}

\begin{abstract}
Background: The expression of MT genes in animal's body is rapidly elevated in response to metal and agents which cause oxidative stress and/or inflammation. The MTF-1 plays an essential role in regulating transcription of MT gene in response to metal ions and oxidative stress. Metalloviatamin complex was found to exhibit anti-tumor and anti-inflammatory activity, cytoprotective effect and reduces oxidative stress.

Objectives: The study was designed to evaluate effects of a daily dose of copper nicotinate complex (CNC) on metallothionein-III (MT-III) and metal-responsive transcription factor -1 (MTF-1) expression during 4-dimethylaminoazobenzene (DAB) exposure.

Methods: Ninety rats were divided into five groups. Group I rats were fed on standard diet and was considered the control group; group II rats were fed on standard diet containing DAB $(0.06 \mathrm{~g} / 100 \mathrm{~g}$ diet daily) for six months; group III rats received CNC dissolved in saline solution $(1 \mathrm{mg} / \mathrm{kg}$ body weight daily) for six months; group IV rats were pretreated with $\mathrm{CNC}$ one month before DAB; group V rats were post treated with CNC after one month of starting feeding on DAB. MT-III and MTF-1 genes expression was assayed by PCR. Renal histopathological changes were examined by light microscopy. Results: Genes expression in all groups was statistically high at all time intervals as compared with control group, while it was decreased in groups III, IV and V as compared to cancer group (II). In group IV and $\mathrm{V}$, the genes expression was statistically increased as compared with group III. MT expression in control group declined with age, while it was higher at $6^{\text {th }}$ month than $2^{\text {nd }}$ and $4^{\text {th }}$ month in group II. MTF-1 expression was increased at $4^{\text {th }}$ month followed by decrease at $6^{\text {th }}$ month in all studied groups. These results were confirmed by histopathological change. There was an increase in pyknotic and necrotic nuclei in tubular epithelial cells and a mild dilatation of renal tubules.

Conclusion: Scavenging ROS during DAB-induced oxidative stress may be the major role of MT. CNC causes a partial improvement in the genes expression as well as renal tubules, so CNC may be a promising candidate used for protection against oxidative stress.
\end{abstract}

Available on line at: www.jhiph.alexu.edu.eg

¥Correspondence:

Email: neveen39@yahoo.com

Suggested Citations: Hussein NA, Yehia MAH. Effects of Copper Nicotinate Complex on Renal Metallothionein and MetalResponsive Transcription Factor 1 Genes Expression during 4-Dimethylaminoazobenzene Exposure in Rats. JHIPH 2015:45(2):76-83.

Keywords: Copper nicotinate complex, 4-Dimethylaminoazobenzene, Metallothionein, Metalresponsive transcription factor- 1 .

\section{INTRODUCTION}

$\mathrm{M}$ etallothioneins (MTs) are intracellular low molecular weight metal-binding proteins with high cysteine content (20 of 61-62 amino acids). ${ }^{(1)}$ There are several MT genes in mammalian genome, which encode at least four metallothioneins. In rodents MTs are controlled by 4 genes placed on chromosome 8 (MT-I, MT-II, MT-III and MT-IV, all are functional, which code for apo-proteins MT-1, MT2, MT-3 and MT-4, respectively), whereas human MTs are controlled by 17 genes on chromosome 16, of which 10 are functional. ${ }^{(2)}$ In mammals, MTs have been presented largely in the cell cytoplasm, but also in lysosomes, mitochondria and nuclei. MT-1 and MT-2 are localized in most tissues; MT-3 is mainly found in heart, kidney, brain and reproductive organs, whereas MT-4 is restricted to the squamous epithelia. ${ }^{(3)}$ The renal cell carcinoma shows three different type of expression as MT-2A elevation, MT-1A decline and MT-1G transcripts. Expression of the MT-3 isoform has been reported in the tubules of normal kidney as well as 
in renal cell carcinoma along with other isoform. ${ }^{(4)}$ The major physiological functions of MTs include homeostasis, storage and transport of essential metals $\mathrm{Zn}$ and $\mathrm{Cu}$, protection against cytotoxicity of toxic metals and scavenging free radicals (ROS and RNS) generated in oxidative stress (anti-inflammatory, antioxidant and antiapoptotic functions). ${ }^{(3,5)}$ MT expression is induced by a multiple factors such as pro- and anti-inflammatory mediators including reactive oxygen species, antioxidants, glucocorticoids, endotoxin, and cytokines (IL-6, TNF- $\alpha$, interferons). ${ }^{(6)}$

The metal-responsive transcription factor-1 (MTF-1 or MRE-binding transcription factor-1 or metal regulatory transcription factor-1) is an effective transcriptional regulator involved in cellular adaptation to a variety of stresses such as oxidative stress, heavy metals exposure or hypoxia. MTF-1 is the most important activator of metallothionein genes. ${ }^{(7)}$

The metalloviatamin; copper (I)-nicotinate complex $\left[\mathrm{CuCl}(\mathrm{HNA})_{2}\right]$; was found to exhibit various bioactivities such as anti-tumor and anti-inflammatory activity ${ }^{(8)}$, cytoprotective effect, superoxide dismutase (SOD) mimic activity. It was also found that it prevents gastric congestion and capillary damage, stimulates blood flow and reduces lipid peroxidation and oxidative stress markers such as nitric oxide. ${ }^{(9)}$

So, the objective of this study was to evaluate the effect of copper (I)-nicotinate complex on rat renal MTIII and MTF-1 mRNA genes expression during 4dimethylaminoazobenzene (DAB) exposure.

\section{METHODS}

Ninety male albino rats two months old with average weight of $120-150 \mathrm{~g}$ were used. They were housed in plastic cages at $23-24{ }^{\circ} \mathrm{C}$ with a 12 -h light and dark cycle. All rats were given free access to standard chewing commercial pellets [ $25 \%$ protein, $11 \%$ fats, $6 \%$ fibers, $12 \%$ moisture, $8 \%$ ash $(\mathrm{Ca}, \mathrm{Ph}, \mathrm{P}$ and $\mathrm{Mn})$ and $38 \%$ nitrogen free extract (starch, glucose, fructose, sucrose lactose)] and tap water. All animal experiments were performed according to protocols approved by the Animal Care and use Ethics Committee of Medical Research Institute, Alexandria University, Egypt.

Rats were divided into five groups consisting of 18 animals each:

Group I: rats were fed on standard diet and served as the control group.

Group II (cancer group): rats were fed on standard diet containing DAB $(0.06 \mathrm{~g} / 100 \mathrm{~g}$ diet $)$ daily for six months. ${ }^{(10)}$

Group III: rats were fed on standard diet and received a daily dose of copper nicotinate complex dissolved in saline solution (CNC, $1 \mathrm{mg} / \mathrm{kg}$ body weight) by oral gavage for six months. ${ }^{(1)}$

Group IV: rats were fed on standard diet and pretreated orally with $\mathrm{CNC}(1 \mathrm{mg} / \mathrm{kg}$ body weight/day); one month before feeding on DAB $(0.06 \mathrm{~g} / 100 \mathrm{~g}$ diet/day) and continued until the end of the experiment (six months). Group V: rats were fed on standard diet and post treated orally with $\mathrm{CNC}(1 \mathrm{mg} / \mathrm{kg}$ body weight/day) after one month of starting feeding on DAB $(0.06 \mathrm{~g} / 100 \mathrm{~g}$ diet/day) and continued until the end of the experiment (six months).

In a time-course experiment, six rats of each group were randomly chosen and sacrificed under light ether anesthesia at 2, 4 and 6 months from the start of the experiment. The rats of group I represent the control group for the other groups at each time interval. The kidney tissues of rats were removed and immediately divided into two parts; the first part was used for total RNA extraction and the second part was fixed in $10 \%$ formalin for histological examination.

Semi-quantification of MT-III mRNA and MTF-1 mRNA gene expression by PCR ${ }^{(12,13)}$

1. RNA extraction:

Total RNA was extracted using Gene JET $^{\mathrm{TM}}$ RNA Purification Kit (Fermentas) following the manufacturer's instructions. The presence of RNA extract was detected by electrophoresis using a $1 \%$ agarose gel stained with ethidium bromide $(0.5 \mu \mathrm{g} / \mathrm{ml})$ for $40 \mathrm{~min}$ at $100 \mathrm{~V}$ and the gel was observed under UV light. The eluted RNA was collected immediately, placed in ice or stored at $20^{\circ} \mathrm{C}$ for further processing.

\section{2. cDNA preparation}

cDNAs were synthesized from the mRNA by RevertAid

${ }^{\mathrm{TM}}$ First Strand cDNA synthesis Kit (Fermentas) using a PCR thermocycler (Applied Biosystem, Foster City, CA, USA). cDNA prepared for conventional PCR was stored at 15 to $25^{\circ} \mathrm{C}$

\section{PCR:}

\section{3.a: MT-III mRNA}

The expression level of MT-III mRNA was measured using specific primers, forward 5'GGAATTCCGCCTGGATATGGAC-3` and reverse 5 'GGGGTACCCCCATAGGCTGTGTGG-3' to amplify 3'-untranslated region of MT-III cDNA (bases 251-387) with simultaneous amplification of $\beta$-actin as an internal control (forward, 5'CATGGATGACGATATCGCT-3' and reverse 5'CATGAGGTAGTCTGTCAGGT-3`). PCR was performed with initial DNA denaturation at $95^{\circ} \mathrm{C}$ for 10 min and then 35 cycles of denaturation at $95{ }^{\circ} \mathrm{C}$ for 1 min, annealing at $55^{\circ} \mathrm{C}$ for $1 \mathrm{~min}$ and extension at $72^{\circ} \mathrm{C}$ for $2 \mathrm{~min}$ followed by an additional elongation step at 72 ${ }^{\circ} \mathrm{C}$ for $10 \mathrm{~min}$. The amplification products were separated electrophoretically on $2 \%$ agarose gel with ethidium bromide $(0.5 \mu \mathrm{g} / \mathrm{ml})$ and analyzed by photography.

\section{3.b: MTF-1 mRNA}

For semi-quantitative analysis of MTF-1 gene expression, specific primers were used (forward, 5'TGCGAGTGCACACAAAGGAGAA-3'; reverse, 5'TGAGACTGTACTGAGTGCTAAA-3`and

glyceraldehyde-3-phosphate dehydrogenase as an internal control (GAPDH; forward primer, 5 'GTGGACATTGTTGCCATCAACGAC-3`; reverse primer 5'-TTTCTCGTGGTTCACACCCATCAC-3').

The PCR was carried out as follows: initial DNA denaturation for 2 min at $94{ }^{\circ} \mathrm{C}$, one cycle; followed by 30 cycles of denaturation for $30 \mathrm{~s}$ at $94^{\circ} \mathrm{C}$, annealing for $30 \mathrm{~s}$ at $60{ }^{\circ} \mathrm{C}$, and extension for $1 \mathrm{~min}$ at $72{ }^{\circ} \mathrm{C}$, then an additional elongation step at $72{ }^{\circ} \mathrm{C}$ for $10 \mathrm{~min}$. Aliquots of the PCR mixtures were separated on $2 \%$ agarose gel 
stained with ethidium bromide $(0.5 \mu \mathrm{g} / \mathrm{ml})$ and photographed.

The bands of both genes were scanned and the data were analyzed using UVPDOC-ITLS ${ }^{\mathrm{TM}}$ Image, acquisition and analysis software (Ultra-Violet product, Ltd. Cambridge, UK) that analyze the relative band density to $\beta$-actin band for MT-III mRNA or to GAPDH for MTF-1 mRNA.

Statistical analysis

Data were fed to the computer using IBM SPSS software package version 20.0. Quantitative data were described using mean and standard deviation. One-way analysis of variance (ANOVA) was used to establish the significance of differences among the different groups.
Probability values $(p)<0.05$ were considered to be statistically significant.

\section{Molecular results}

\section{RESULTS}

The expression of MT-mRNA and MTF-1mRNA in all studied groups was statistically high at all time intervals as compared with control group. The genes mean values (copies) were decreased in groups III, IV and V as compared to cancer group (II). In group IV and V, the genes expression levels were statistically increased as compared with group III but did not show any significant difference when compared with each other (Tables $1 \& 2$ ).

Table (1): MT-mRNA gene expression (copies) in all studied groups at the second, fourth and sixth months of the experiment

\begin{tabular}{llll}
\hline & $\mathbf{2}^{\text {nd }}$ month & $\mathbf{4}^{\text {th }}$ month & $\mathbf{6}^{\text {th }}$ month \\
\hline Control group (I) & $0.870 \pm 0.05$ & $0.742 \pm 0.03$ & $0.371 \pm 0.04$ \\
Cancer group (II) & $1.164 \pm 0.23^{\mathrm{a}}$ & $1.101 \pm 0.15^{\mathrm{a}}$ & $2.400 \pm 0.23^{\mathrm{a}}$ \\
CNC group (III) & $0.903 \pm 0.08^{\mathrm{b}}$ & $0.834 \pm 0.05^{\mathrm{b}}$ & $0.753 \pm 0.02^{\mathrm{ab}}$ \\
CNC before DAB (IV) & $0.993 \pm 0.002^{\mathrm{b}}$ & $0.982 \pm 0.11^{\mathrm{ac}}$ & $0.918 \pm 0.06^{\mathrm{abc}}$ \\
CNC after DAB $(\mathbf{V})$ & $1.003 \pm 0.002^{\mathrm{ab}}$ & $0.973 \pm 0.12^{\mathrm{abc}}$ & $0.991 \pm 0.10^{\mathrm{abc}}$ \\
\hline
\end{tabular}

The mean difference was statistically significant at $\mathrm{p}<0.05$.

ANOVA test used for comparing between the different studied groups.

${ }^{a}$ Comparing with control group (I).

${ }^{\mathrm{b}}$ Comparing groups III, IV, V with group II.

${ }^{\mathrm{c}}$ Comparing groups IV, V with group III.

Table (2): MTF-1mRNA gene expression (copies) in all studied groups at the second, fourth and sixth months of the experiment

\begin{tabular}{|c|c|c|c|}
\hline & $2^{\text {nd }}$ month & $4^{\text {th }}$ month & $6^{\text {th }}$ month \\
\hline Control group (I) & $0.189 \pm 0.01$ & $0.282 \pm 0.01$ & $0.152 \pm 0.01$ \\
\hline Cancer group (II) & $0.293 \pm 0.01^{\mathrm{a}}$ & $0.513 \pm 0.02^{\mathrm{a}}$ & $0.336 \pm 0.03^{\mathrm{a}}$ \\
\hline CNC group (III) & $0.243 \pm 0.03^{\mathrm{ab}}$ & $0.454 \pm 0.04^{\mathrm{ab}}$ & $0.233 \pm 0.02^{\mathrm{ab}}$ \\
\hline CNC before DAB (IV) & $0.274 \pm 0.01^{\mathrm{abc}}$ & $0.503 \pm 0.02^{\mathrm{ac}}$ & $0.269 \pm 0.02^{\mathrm{abc}}$ \\
\hline CNC after DAB (V) & $0.276 \pm 0.01^{\mathrm{abc}}$ & $0.488 \pm 0.06^{\mathrm{a}}$ & $0.263 \pm 0.01^{\mathrm{abc}}$ \\
\hline
\end{tabular}

The mean difference was statistically significant at $\mathrm{p}<0.05$.

ANOVA test used for comparing between the different studied groups.

${ }^{\text {a }}$ Comparing with control group (I).

${ }^{\mathrm{b}}$ Comparing groups III, IV, V with group II.

${ }^{\mathrm{c}}$ Comparing groups IV, $\mathrm{V}$ with group III.

The expression of MT-mRNA in control group declined with age, while at sixth month it was higher than second and fourth month in gp II. The MTmRNA expression in gp III, IV and V was nearly similar at all time intervals, whereas the expression of MTF-1 was increased in all studied groups at fourth month followed by decrease at sixth month (Figure 1). 


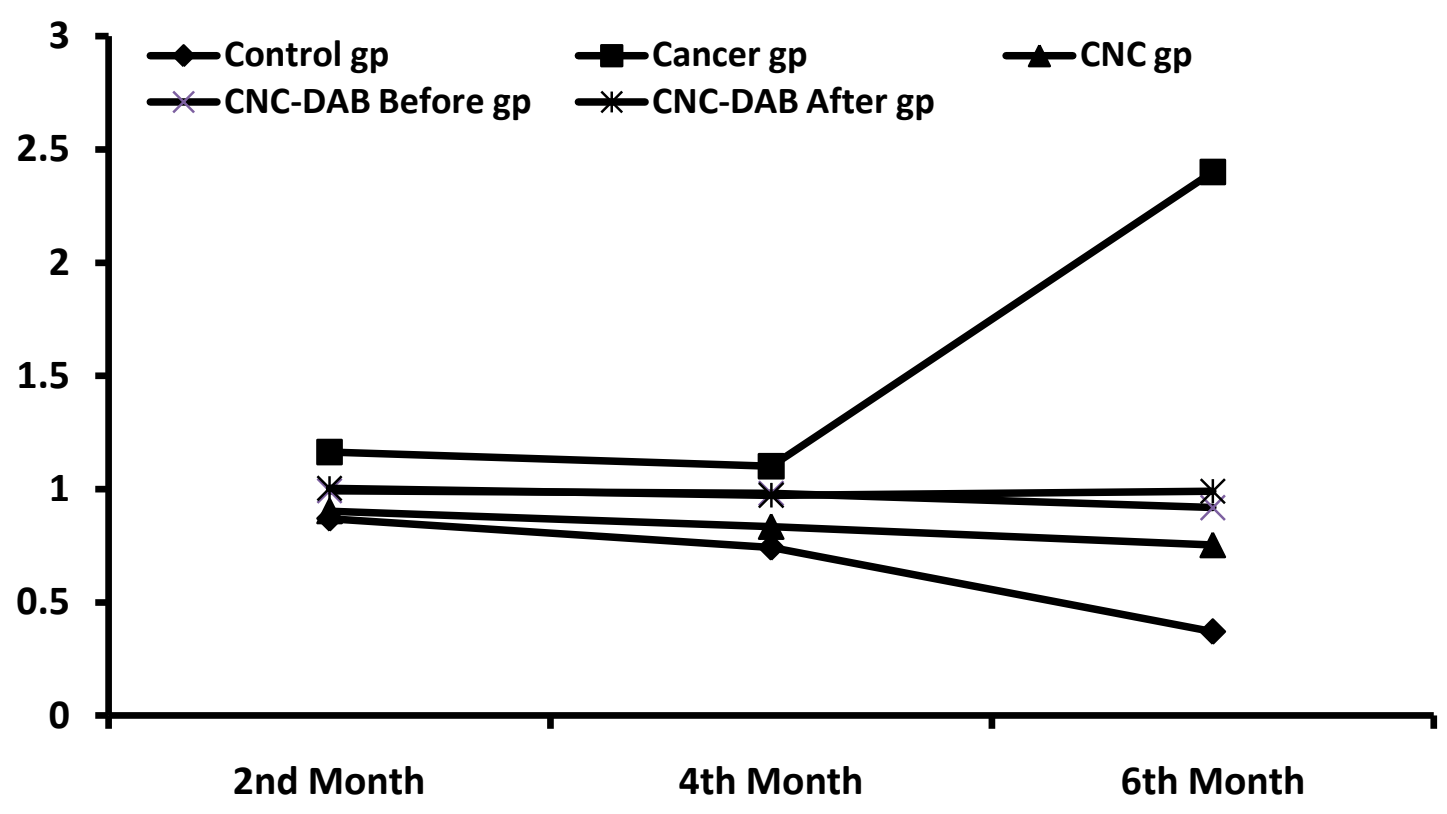

MT- mRNA

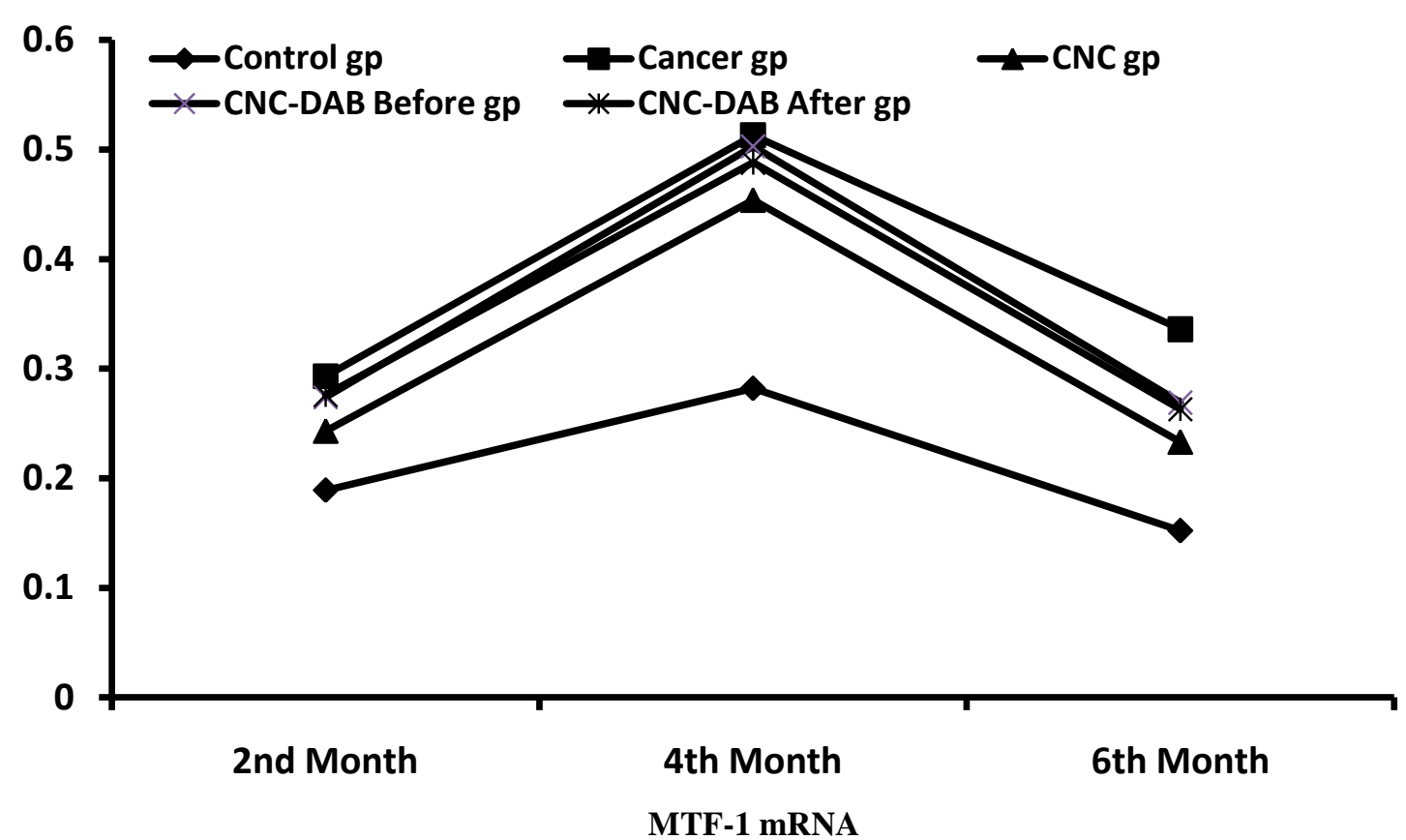

Figure (1): MT-mRNA and MTF-1 mRNA expression during six months

Histopathological results

The renal histological feature of the control group (I) showed normal glomeruli and tubules (Fig 2), whereas that of the cancer group (II) showed most degeneration of renal tubular noticed by marked dilatation of renal tubule, vesiculated and necrotic tubular epithelial cells as well as, hypertrophic glomeruli (Fig 3a). Studies of several sections of rats received $\mathrm{CuCl}$ ( $\mathrm{HNA})_{2}$ showed minimal urinary space, mild dilatation of renal tubules, pyknotic nuclei of the mesangial and epithelial tubular cells (Fig 3b). In group IV, regenerative tubules were noticed with mild lose their adhesion (Fig 3c). An increase in atrophied glomeruli with area of proliferating and necrotic and pyknotic tubules epithelial cell as well as mild dilatation of renal tubules was observed in groupV (Fig 3d). There was no difference in the histopathological feature with the time duration in same groups (Figures 3 and 4). 




Figure (2): Paraffin section micrograph of control rat kidney showing the minimal urinary space (US), normal basophilic mesangial cells (MS), and mild dilatation of normal tubules (RT)


Figure (3): Paraffin section micrograph of rat kidney at $2^{\text {nd }}$ month

(a) Cancer group (II): moderate necrotic tubular epithelial cells as well as atrophy glomeruli (AG) and infiltrating lymphocytes.

(b) CNC group (III): mild adhesion of renal tubules (RT), pyknotic nuclei of the mesangial and epithelial tubular cells.

(c) CNC before DAB group (IV): normal glomeruli with mesangial cells (MC) and normal renal tubules (RT) with pyknotic nuclear epithelial cell.

(d) CNC after BAB group (V): mild atrophy glomeruli (AG) area of degenerative renal tubules with epithelial pyknotic nuclei as well as increased necrotic tubular epithelial cell. 


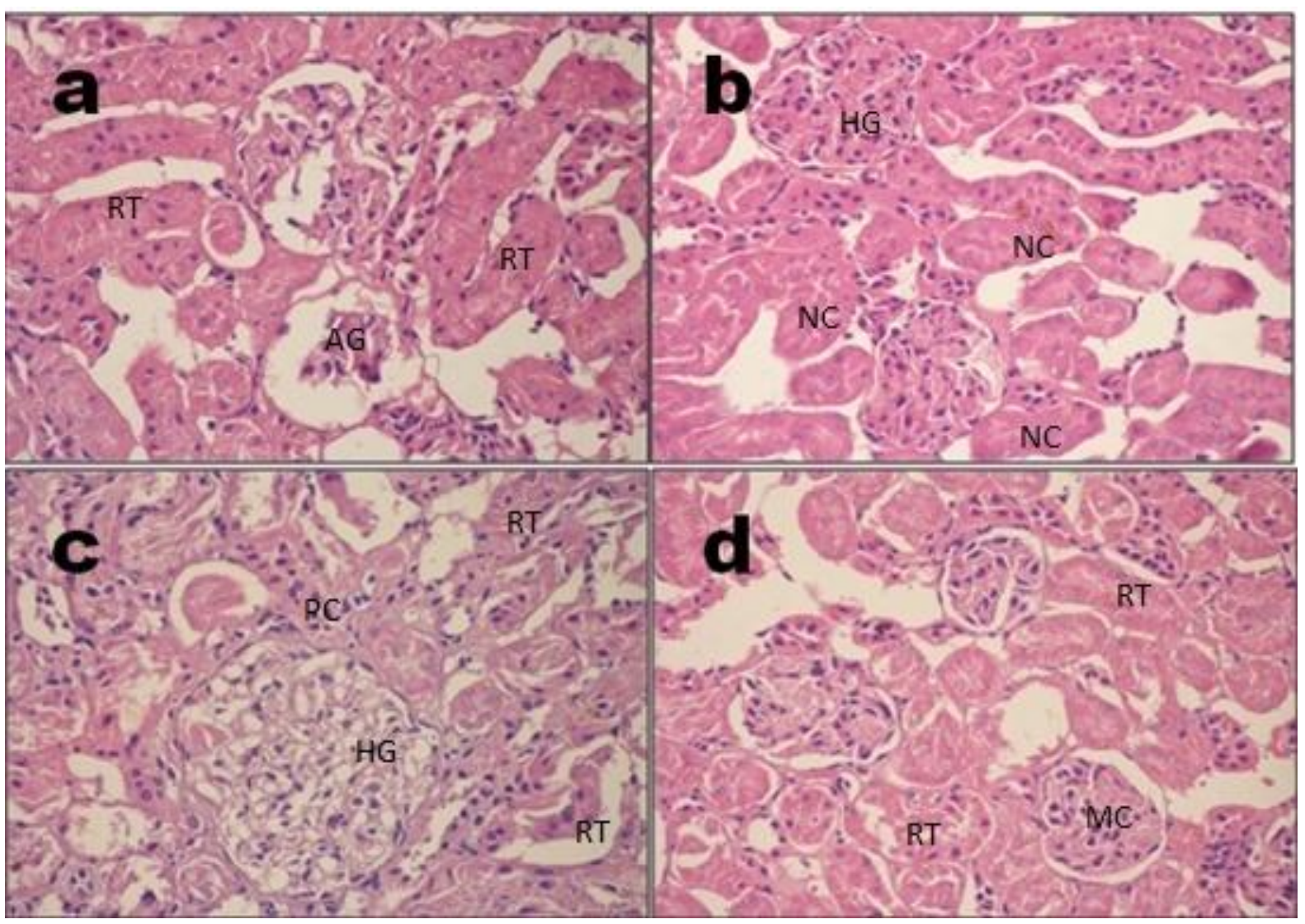

Figure (4): Paraffin section micrograph of rat kidney at $6^{\text {nd }}$ month

(a) Cancer group (II): sever necrotic tubular epithelial cells as well as, hyperemic and atrophy glomeruli (AG) and infiltrating lymphocytes.

(b) CNC group (III): normal differentiated mesangial cells. Regenerative tubules were noticed with normal nuclei and contacted cytoplasm.

(c) CNC before DAB group (IV): pyknotic mesangial cell nuclei and epithelial cells of renal tubules, as well as hyaline castes of renal tubules and infiltration of lymphocytes.

(d) $\mathrm{CNC}$ after $\mathrm{BAB}$ group $(\mathrm{V})$ : marked dilatation of renal tubules having necrotic $(\mathrm{NC})$ and pyknotic epithelia nuclei cells, glomeruli with mild urinary space and pyknotic nuclei of mesangial cells.

Table (3): Distribution of the histopathological changes of the kidney tissues in all studied groups

\begin{tabular}{|c|c|c|c|c|c|}
\hline Histological alterations & Group I & Group II & Group III & Group IV & Group V \\
\hline Glomerulus atrophy & $5 \%$ & $40 \%$ & $11 \%$ & $13 \%$ & $18 \%$ \\
\hline Tubular degeneration & + & ++ & + & + & + \\
\hline Tubular necrosis & + & +++ & + & + & ++ \\
\hline Tubular pyknotic nuclei & ++ & & + & ++ & ++ \\
\hline
\end{tabular}

\section{DISCUSSION}

The expression of MT genes in animal's body is rapidly elevated in response to metal and agents which cause oxidative stress and / or inflammation. The MTF-1 plays an essential role in regulating transcription of MT gene in response to metal ions and oxidative stress. ${ }^{(14)}$

The study was indicated that both MT mRNA and MTF-1 mRNA expression in all groups were significantly higher than the control group at all time intervals (after 2, 4 and 6 months from the onset of the experiment). 4-dimethylaminoazobenzene (DAB) is a carcinogenic amino azo dye and metabolically demethylated by microsome cytochrome $\mathrm{p}-450$ to give 4- amino azo benzene (AAB) after which N- hydroxylation and esterification (by sulfo-transferase) may occur. The mechanism of DAB carcinogenic action has been attributed principally to the formation of DNA adducts following metabolic oxidation of the amino group ${ }^{(15)}$ leading to high levels of reactive oxygen species generation which can affect the genes transcription. ${ }^{(16)}$

The molecular mechanism of MT gene induction results from an enhanced transcription of structural genes following interaction of specific stimuli (trans-acting factors, such as metal and ROS) with response elements (RE, cis-acting elements) in the gene promoter. ${ }^{(14)}$ The MTF-1 is the major player in regulating MT gene expression in physiological conditions and in response to metal ions. ROS can activate MTF-1 indirectly, by 
mobilizing $\mathrm{Zn}$ from intracellular stores and/or by activating some other intracellular signal pathways such as signal transduction molecules (STM). ${ }^{(17)} \mathrm{Zn}$ binds to an inactive cytoplasmic apo-MTF-1 and activates it by inducing phosphorylation of the protein. The activated complex migrates to the nucleus, where it binds to metal response element (MRE) and stimulates the synthesis of MT mRNA. ${ }^{(18)}$ Furthermore, MTF-1 may be existed in an inactive form in a complex with MT (MT-MTF1 ); $\mathrm{Zn}$ could activate MTF-1indirectly, by binding to MT in the complex and releasing MT-Zn; the liberated apo-MTF-1 would then be further activated by $\mathrm{Zn}$ and bind to MRE. This may represent a basic feed-back mechanism that would control the MT production in normal and stressful conditions. (19) Moreover, the MT gene transcription via antioxidant response element (ARE) can be promoted by various ARE-binding proteins, which can be activated by metal and ROS. A synergistic activation of the MT gene expression via MRE and ARE may be important in nephrotoxicity induced by toxic metals, when the intracellular high concentrations of these metals associate with the increased production of ROS. ${ }^{(20)}$

The obtained results were denoted that the expression of both genes in $\mathrm{Cu}$ complex-received group (group III) was significantly increased as compared to the control group. Previous study stated that the absorption of $\mathrm{CuCl}$ (HNA) $)_{2}$ complex to different organs was as its administered form without ligand exchange and that led to the copper distribution to tissues in magnitude up to two fold of its normal content. ${ }^{(21)}$ Besides, the kidney gained a considerable amount of the administered $\mathrm{CuCl}(\mathrm{HNA})_{2}$ and the filtered copper may undergo ligand exchange in distal tubules and that account for the participation of the kidney in copper conservation. (22) Accordingly, the high expression of both gene in kidney may be attributed to the increased accumulation of copper administration, since MT has a pivotal role in homeostasis of $\mathrm{Zn}$ and $\mathrm{Cu}$ (trapping, storage, distribution and release) ${ }^{(5)}$ and with excess copper, MT may release zinc ions and bind other elements instead. ${ }^{(7)}$ Furthermore, MT gene expression is induced by heavy metal ions through several mechanisms that facilitate MTF-1 transport to the nucleus and induce DNA binding, where it exerts an effect on gene transcription such as MT. ${ }^{(23)}$

The higher expression of both genes in groups IV and $\mathrm{V}$ than the control group as well as the CNCreceived group may be due to the carcinogenic effect of DAB which generate free radicals (ROS and RNS) as well as oxidative stress. Whereas, comparing with cancer group, the genes expression was statistically low in group IV (pretreated group) and group V but still higher than that of the control group.

The improvement in renal MT mRNA and MTF-1mRNA expression in groups IV and $\mathrm{V}$ as compared to group II could be mostly attributed to the effect of $\mathrm{Cu}$ nicotinate complex. These results are in accordance with previous study which elucidate that $\mathrm{CuCl}(\mathrm{HNA})_{2}$ enhance cellular defense mechanisms against free radicals and lipid peroxidation by increasing utilization of copper in cells and tissues. ${ }^{(24)}$ The absorbed copper complex in cells and tissues could react with apoenzymes and apoproteins leading to formation of copperdependent enzymes and proteins respectively; these are mostly antioxidant. ${ }^{(25)}$ These reactions may account to suppress copper-induced lipid peroxidation. $^{(26)}$ Also the pretreatment with $\mathrm{CuCl}$ (HNA $)_{2}$ had gastroprotective effect by preventing the down regulation in the antioxidants activity whereby fighting each of peroxide elevation and subsequently lipid peroxidation. The blocked in peroxide level by the antioxidant activity of $\mathrm{CuCl}$ (HNA $)_{2}$ emphasize its role as a potent antioxidant, since $\mathrm{CuCl}$ (HNA) $)_{2}$ affect activity of several cuproenzymes controlling oxidation-reduction reactions (such as copper-zinc superoxide dismutase enzyme) as a cofactor and as a prosthetic component. $^{(27)}$

The present histopathological examination, revealed more changes of the renal tubules architecture, mostly appeared for the necrotic to pyknotic tubular epithelial cells as well as some vesiculated nuclei. These changes of renal nuclear epithelial cells revealed the disturbance balance of nucleic acids or nucleoprotein structure. So, it could be due the cupper binding to newly nucleoprotein synthesis. Also it revealed the more expression of the MT gene in all groups as well as the role of this gene expression caused due to the $\mathrm{Cu}$ nicotinate complex binding. MT expression pattern will be changed in the body when any diseases caused due to metal factor, therefore the $\mathrm{Cu}$ complex may trigger the expression of MT in animal's body.

The obtained findings showed that in control group, the expression of MT-mRNA in the renal tissue declines with age. Nordberg 1998 repot that the renal tissues capacity to produce MT may be decreasing in old age due to less efficient protein synthesis. ${ }^{(28)}$ Furthermore, when extracellular metal concentration decreased, Zn dissociated from MT resulting in a faster rate of MT degradation. ${ }^{(29)}$ On the other hand in cancer group, the expression of MT-mRNA is higher at sixth month than second and fourth month. This result may be a normal physiologic response to tumor progression that leads to increase oxidative stress and ROS.

Either after second, fourth or sixth months, the MTmRNA expression in groups III, IV and V (CNC group and CNC-treated groups) is nearly similar that is due to the presence of $\mathrm{CNC}$ which is source of $\mathrm{Cu}$ that induce MT expression. $\mathrm{Cu}$ bound to MT is present as long as cells maintain the capacity to synthesize sufficient MT to accommodate $\mathrm{Cu}$ within cells. ${ }^{(30)}$

The expression of MTF-1 is increased in all studied groups at fourth month follow by decrease at sixth month. MTF-1 genes are transcriptionally activated by $\mathrm{Zn}$ load, in addition, to other inducers such as $\mathrm{Cd}$, copper and hydrogen peroxide. The effect of these inducers is 
indirectly proportionate by liberating $\mathrm{Zn}$ from intracellular stores such as metallothionein. ${ }^{(7,31)}$ In control group, the downregulation of MTF-1 expression is due to decline in MT expression by aging. ${ }^{(28)}$ At sixth month, the level of $\mathrm{H}_{2} \mathrm{O}_{2}$ and $\mathrm{Cu}$ is high due to DAB effect and CNC administration respectively. MTs are normally saturated with highly abundant $\mathrm{Zn}$ and release $\mathrm{Zn}$ upon exposure to copper or $\mathrm{H}_{2} \mathrm{O}_{2}$ leading to MTF-1 activation. The downregulation of MTF-1 following its activation is may be due to thioneine (metal-free form of MT, apo-MT); bind Zn with high affinity; which inhibit MTF-1 by Zn sequestration. Activation of MTF-1 and subsequent inactivation by newly synthesized apo-MT might be a basic mechanism to regulate MTF-1 activity upon metal load and cellular stress. ${ }^{(32)}$

The current data on the expression of MT and MTF-1 mRNA in renal cell carcinogenesis examined emphasize that, the expression of both genes depend on a lot of stimuli. Scavenging ROS during DAB-induced oxidative stress may be the major role of MT. $\mathrm{Cu}$ nicotinate complex causes a partial improvement in the genes expression levels as well as renal tubules. The protective effect of $\mathrm{Cu}$ nicotinate is more prominent than therapeutic effect. Thus, $\mathrm{Cu}$ nicotinate complex may be a promising candidate used for protection against oxidative stress.

\section{Conflict of Interest: None to declare}

\section{REFERENCES}

1. Isani G, Carpenè E. Metallothioneins, unconventional proteins from unconventional animals: a long journey from nematodes to mammals. Biomolecules. 2014;4:435-57.

2. Miles AT, Hawksworth GM, Beattie JH, Rodilla V. Induction, regulation, degradation and biological significance of mammalian metallothioneins. Crit Rev Biochem Mol Biol. 2000;35:35-70

3. Sabolic I, Breljak D, Skarica M, Herak-Kramberger CM. Role of metallothionein in cadmium traffic and toxicity in kidneys and other mammalian organs. Biometals. 2010;23:897-926.

4. George CM, Jayasurya A, Boon-Huat B. Metallothioneins in human tumors and potential roles in carcinogenesis. Mutation Res. 2003;201-9.

5. Ruttkay-Nedecky B, Nejdl L, Gumulec J, Zitka O, Masarik $\mathrm{M}$, Eckschlager $\mathrm{T}$, et al. The role of metallothionein in oxidative stress. Int J Mol Sci. 2013;14:6044-66.

6. Lynes MA, Hidalgo J, Manso Y, Devisscher L, Laukens D, Lawrence DA. Metallothionein and stress combine to affect multiple organ systems. Cell Stress Chaperones 2014;19:605-11.

7. Günther V, Lindert U, Schaffner W. The taste of heavy metals: Gene regulation by MTF-1. Biochim Biophys Acta. 2012;1823:1416-25.

8. Belicchi MF, Bisceglie F, Pelosi G, Sassi M, Tarasconi P, Cornia M, et al. Synthesis, characterization and biological activity of two new polymeric copper (II) complexes with alpha-ketoglutaric acid thiosemicarbazone. J Inorg Biochem. 2002;10:36-44

9. EL-Saadani M, Nassar A, Abou-El-Ela SH, El-Metwalli T, Nafady AM. The protective effect of copper complexes against gastric mucosal ulcer in rats. Biochem Pharmacol. 1993;46:1011-8.

10. Kuroda K, Akao M. Inhibitory effect of fumaric acid on 3'Methyl-4- (Dimethylamino) Azobenzene-induced hepatocarcinogenesis in rats. Chem Pharm Bull 1989 (Tokyo);37:1345-6.
11. Atta HA., Fathy S, Goher M, Jan R, Kamel G, Mounier M.S., Nasr M.S. Prolonged of high doses of copper nicotinate to rats. Effect on biochemical and cellular constituents of blood and on copper level on serum, liver and muscle. Int J Med. 2009;1:178-83

12. Kobayashi H, Uchida Y, Ihara Y, Nakajima K, KohsKa S, Miyatake T, Tsuji S. Molecular cloning of rat growth inhibitory factor cDNA and the expression in the central nervous system. Brain Res Mol Brain Res. 1993;19:188-94.

13. Hara H, Aizenman E. A molecular technique for detecting the liberation of intracellular zinc in cultured neurons. J Neurosci Methods. 2004;137:175-180.

14. Andrews GK. Regulation of metallothionein gene expression by oxidative stress and metal ions. Biochem Pharmacol 2000;59:95-104.

15. Ohnishi S, Murata M, Degawa M, Kawanishi S. Oxidative DNA damage induced by an N-hydroxy metabolite of carcinogenic 4dimethylaminoazobenzene. Jpn J Cancer Res 2001; 92: 23-9.

16. Klauning JE, Kamendulis LM, Hocevar BA. Oxidative stress and oxidative damage in carcinogenesis. Toxicol Pathol. 2009;38:96-109.

17. Dalton TP, Li QW, Bittel D, Liang LC, Andrews GK. Oxidative stress activates metal-responsive transcription factor -1 binding activity. Occupancy in vivo of metal response elements in metallothionein-1 gene promoter. $\mathrm{J}$ Biol Chem. 1996;271:26233-41.

18. LaRochelle O, Gagne V, Charron J, Soh J, Seguin C. phosphorylation is involved in the activation of metal-regulatory transcription factor-1 in response to metal ions. J Biol Chem. 2001;276:41879-88.

19. Palmiter RD. The elusive function of metallothioneins. Proc Natl Acad Sci. 1998;95:8428-30.

20. Sabolic I, Herak-Kramberger CM, Antolovic R, Breton S, Brown D. Loss of basolateral invaginations in proximal tubules of cadmium intoxicated rats is independent of microtubules and clathrin. Toxicol. 2006;218:149-63.

21. EL-Saadani MA, El-Sawi Nagw, Nafady AM. Pharmacokinetics of complexed copper in rats: characterization of biochemical and cellular responses. J Med Res Inst. 2003;24:14-28.

22. Sorenson JRJ. Biology of copper complexes. Human Press Inc, Clifton, New Jersey. 1987; pp: 6.

23. Lin MC, Liu YC, Tam MF, Lu YJ, Hsieh YT, Lin LY. PTEN interacts with metal-responsive transcription factor 1 and stimulates its transcriptional activity. Biochem J. 2012;441:367-77.

24. El Saadani MA. A combination therapy with copper nicotinate complex reduces the adverse effects of 5-flurouracil on patients with hepatocellular carcinoma. J Exp Ther Oncol. 2004;4:19-24.

25. Sorenson JRJ. Copper complex offer a physiological approach to treatment of chronic diseases. Prog Med Chem. 1989;26:437-68.

26. Hanhel D, Huber T, Kurze V, Beyer K, Engelmann B. Contribution of copper binding to the inhibition of lipid oxidation by plasmalogen phospholipids. Biochem J. 1999;340:377-83.

27. Tourkey MJF, Abdul-Aziz KK. A pioneer study on the antiulcer activities of copper nicotinate complex $\mathrm{CuCl}(\mathrm{HNA})_{2}$ in experimental gastric ulcer induced by aspirin-pyloris ligation model (shay model). Biochem Pharmacotherapy. 2009;63:194-201.

28. Nordberg M. Metallothionein: historical review and state of knowledge. Talanta 1998;46:243-54.

29. Tate DJ, Neiusome DA, Olive PD. Metallothionein Shows an age-related decrease in human macular retinal pigment epithelium. Invest Ophthalmol Vis Sci 1993; 34: 2348-51.

30. Santon A, Albergoni V, Sturniolo GC, Irato P. Evaluation of MT expression and detection of apoptotic cells in LEC rat kidneys. Biochim Biophy Acta. 2004;1688:223-31.

31. Grzywacz A, Gdula-Argasińska J, Muszyńska B, TyszkaCzochara M, Librowski $\mathrm{T}$, et al. Metal responsive transcription factor 1 (MTF-1) regulates zinc dependent cellular processes at the molecular level. Acta Biochim Polonica. 2015;62:491-8

32. Zhang BO, Georgiev O, Hagmann M, Gunes C, Cramer M, Faller $\mathrm{P}$, et al. Activity of metal- responsive transcription factor- 1 by toxic heavy metals and $\mathrm{H}_{2} \mathrm{O}_{2}$ in vitro is modulated by metallothionein. Mol Cell Biol. 2003;23:8471-85. 